\title{
Exploration of Effective Spatial Performance of Accessible Neighbourhood Green (ANG), Including its Proportion and Standard Distance from user in Dhanmondi Residential Area, Dhaka
}

\author{
I.M. Badhan ${ }^{1 *}$ and S.W. Ching ${ }^{2}$ \\ ${ }^{1}$ Department of Architecture, Ahsanullah University of Science and Technology, Dhaka-1208, Bangladesh \\ ${ }^{2}$ Department of Architecture, State University of Bangladesh, Dhaka-1205, Bangladesh \\ "badhan.arch@aust.edu (Corresponding Author)
}

\section{ARTICLE INFORMATION}

Received: July 13, 2020

Revised: January 18, 2021

Accepted: February 02, 2021

Published Online: March 26, 2021

\section{Keywords:}

Neighbourhood Green, Accessibility,

Proximity, Spatial Performance, Liveability

\section{ABSTRACT}

Background: Urban physical context can be analyzed across three key matrixes (3-P), among others, i.e. place, path, and people. So, pragmatic analysis of compelling spatial performances connecting 3-P requires provoking frequency of people's experience. Acknowledging this issue, the demand for accessible neighborhood green (ANG) at an appropriate distance becomes the primary concern to enhance the quality of life and livability in a city. However, with the continued urban growth and densification, the discrepancy between the demand and supply of open space continues to vary, requiring adjustments to remain responsive. The real-life circumstance results in a shortage of parks and open areas according to demand and supply within accessible distance in Dhaka city.

Purpose: This paper intends to examine this issue through the case of the planned Dhanmondi Residential Area (DRA) in Dhaka. Despite having multiple open spaces in DRA, visitors' frequency varies due to age and gender group accessibility conditions and varying distances. Considering existing spatial norms set by Detail Area Plan (DAP), Dhaka structure plan (DSP), and numerous research works on Dhaka open spaces, the primary inquiry posed here is whether these open spaces are appropriate DRA or not. Therefore, this paper's objective focuses on examining the quality of the physical environment of Neighbourhood public open spaces termed here as accessible neighborhood green (ANG) in DRA to review their adequacy concerning proportion and distance synchronized with the frequency of visits.

Methods: The initial part of the paper focuses on conceptualizing the problem vis-à-vis the existing scenario. Surveys and interviews have been conducted to assess people's perceptions regarding comfort, accessibility, sociability, and user frequency aligned with proximity.

Results: Prediction/analysis or comparisons short idea with the existed theories or experimental results.

Conclusions: The result indicates that the provision of one appropriate ANG within two or three standard blocks apart contributes to enhancing the city dwellers' quality of life.

\section{Introduction}

In the last 30 to 40 years, Dhaka has seen radical changes in its physical environment and declination of quality of life. Accessible neighborhood green (ANG) has prodigious ecological standing in an urban setting, from micro-climatic biodiversity that has undergone man-driven interventions, increasing the toxic environment's risk (Suchana, 2013). Recently this megacity has been ranked as the second least habitable city in the world for the third time, according to the economist intellect unit's 2015 global liveability ranking ("EIU Survey: Dhaka ranked second least liveable city", 2018). Dhaka's structure plan recommends that the percentage of open space ought to be at least $20 \%$ within the urban boundary. But in Dhaka urban greenery or tree-covered spaces finds less than $15 \%$ of the urban landscape. According to the Dhaka Metropolitan Integrated Urban Development Plan - 1995 (DMIUDP-95) (Mowla, 2005), old Dhaka has unplanned organic development having only $5 \%$, and the new Dhaka is mostly planned result still having only about $12 \%$ open space as existing. According to the National Recreation and Park Association (NRPA) Standard, neighborhood 
park ought to be connected to communal paths and sidewalks and must be uninterrupted by any physical barriers and easily accessible, especially for children and senior adults, within at least $1 / 4-1 / 2$ mile service range from habitations (Mirsch, 2002). The question arises with the continued urban growth and densification resulting in the discrepancy between the demand and supply of open space concerning proportion, distance, and appropriate physical environment. The circumstance gradually results in the wrong size and distribution of open areas i.e. ANG in Dhaka city.

\section{Literature Review}

\subsection{Definition of Neighborhood Unit and Accessible Neighborhood Green (ANG)}

The idea of a significant Accessible Neighbourhood Unit has been derived from Clarence Perry's Neighbourhood Unit Concept, developed in the US during the 1920s, to systematically organize and develop urban areas (Carmona, Heath, Oc \& Tiesdell, 2003). Within Perry's proposed Neighbourhood Unit, Six physical attributes have been specified (Carmona, Heath, Oc \& Tiesdell, 2003) as shown below:

(i) Size of the population required to support one elementary school;

(ii) Boundaries - arterial roads would bypass rather than penetrate the unit;

(iii) Open spaces;

(iv) Institutional sites at the central point, so that the sphere of influence coincided with the unit;

(v) Local shops located on the edge of the unit, so that larger unit would be formed at junctions;

(vi) An internal street system is proportional to the expected traffic load.

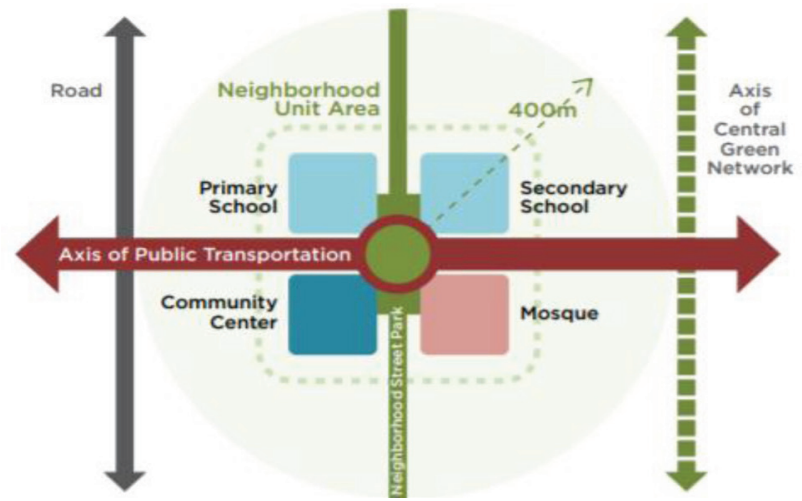

Figure 1: Neighbourhood Unit Area (Source: Dhaka Structure Plan 2016-2035 (2016)).
The possible standard diagram of the neighborhood unit is shown in Figure 1. By exploring several studies on a neighborhood concept, it can be easily perceived that a sustainable neighborhood ought to be walkable (Suchana, 2013; Mowla, 2005), affordable, and accessible from a certain radius.

Neighbourhood green spaces are the spaces that tend to attract a significant proportion of visitors from particular units of the neighborhood or at least two adjacent areas. Depending on their location, people will travel by foot if they live nearby ANG or by car or public transport if they live farther away (Islam, Kawsar \& Ahmed, 2002). Accessibility is generally conferred through a mode of communication or transportation used. But in this paper, the point to be noted is that an urban place has been considered inaccessible requiring public transportation and requiring to cross major roads (Carmona, Heath, Oc \& Tiesdell, 2003; Mowla, 2005). By such neighborhood green spaces, comprehended with predominant attributes like vegetation covering, are used for either recreation or creating a positive social impact on the urban environment within walking distance.

\subsection{Standard Attributes for Depicting Quality of Successful ANG}

Open areas involve community learning and social development. Other spatial factors such as the scale of the green space and the presence of facilities are also thought to influence the utilization of neighborhood green space (Herzele \& Wiedemann, 2003). Accessible green spaces possess two environments:

\section{- Physical Environment}

The physical environment is wherever individuals live, learn, work, and play. People interact with their physical environment through the air they breathe, the water they drink, the houses to live in, and the transportation they access to travel to work and school. These are elements that are tangible and that people can touch.

\section{- Psycho-Social Environment}

Our "environment" includes mutually social determinants of Health and physical environmental determinants of Health. Social impacts on health are embedded within the broader environment in which we tend 
to live. Our psychosocial environment includes our responses to stressors in our lives, from temporary ones such as a traffic jam to major stressors like war, homelessness, or major disease, and the interaction how we respond to them, both individually and as communities.

\subsection{Attributes for Physical Environment}

A probabilistic approach for the physical environment that 'greatly simplified' outdoor activities in public spaces can be divided into three categories. Therefore successful ANGs are expected to have some attributes stated in Table 1:

Table 1: Probabilistic approach for the physical environment.

\begin{tabular}{|l|c|c|}
\hline \multirow{2}{*}{$\begin{array}{l}\text { Necessary activities } \\
\text { compulsory activity mostly } \\
\text { (e.g. going to school or workplace, shopping or waiting for a bus) }\end{array}$} & \multicolumn{1}{|c|}{ Qualities of the physical environment } \\
\hline $\begin{array}{l}\text { Optional activities } \\
\text { Demands wish or time to do so } \\
\text { (Taking a walk to get a deep breath of fresh air, stopping for a coffee in a } \\
\text { street café, people-watching, etc.) }\end{array}$ & & \\
\hline $\begin{array}{l}\text { Social activities } \\
\text { Communal activities } \\
\text { (i.e. merely seeing and hearing other people) }\end{array}$ & & \\
\hline
\end{tabular}

\subsection{Attributes for Psycho-Social Environment}

What public space should provide are summarized in Table 2:

Table 2: Attributes for the psychosocial environment (Carmona, Heath, Oc \& Tiesdell, 2003).

\begin{tabular}{|c|c|c|c|}
\hline Protection & $\begin{array}{l}\text { Protection against traffic and } \\
\text { accidents }\end{array}$ & $\begin{array}{l}\text { Protection against crime and } \\
\text { violence }\end{array}$ & $\begin{array}{l}\text { Protection against unpleasant sense- } \\
\text { experiences }\end{array}$ \\
\hline & $\begin{array}{l}\text { - Traffic accidents } \\
\text { - Fear of accidents }\end{array}$ & $\begin{array}{l}\text { - Streetlife } \\
\text { - Street watching }\end{array}$ & $\begin{array}{l}\text { - Wind } \\
\text { - Rain/cold } \\
\text { - Pollution/dust }\end{array}$ \\
\hline \multirow[t]{4}{*}{ Comfort } & Possibilities for walking & $\begin{array}{l}\text { Possibilities for standing/ } \\
\text { staying }\end{array}$ & Possibilities for sitting \\
\hline & $\begin{array}{l}\text { - The untiring layout of streets } \\
\text { - No obstacles } \\
\text { - Good surface }\end{array}$ & $\begin{array}{l}\text { - Attractive edges - edge effects } \\
\text { - Defined spots/supports for } \\
\text { staying }\end{array}$ & $\begin{array}{l}\text { - Benches for resting } \\
\text { - Zones for sitting }\end{array}$ \\
\hline & Possibilities for seeing & $\begin{array}{l}\text { Possibilities for hearing/ } \\
\text { talking }\end{array}$ & $\begin{array}{l}\text { Possibilities for play/unfolding } \\
\text { activities }\end{array}$ \\
\hline & $\begin{array}{l}\text { - Seeing distance } \\
\text { - Unhindered interesting view }\end{array}$ & $\begin{array}{l}\text { - Low noise levels } \\
\text { - Bench arrangements - 'talk } \\
\text { scapes' }\end{array}$ & - Invitation to physical activity \\
\hline \multirow[t]{2}{*}{ Enjoyment } & Scale & $\begin{array}{l}\text { Possibilities for enjoying } \\
\text { positive aspects of climate }\end{array}$ & $\begin{array}{l}\text { Aesthetic quality/positive sense- } \\
\text { experiences }\end{array}$ \\
\hline & $\begin{array}{l}\text { Dimensions of buildings and } \\
\text { spaces important to human scale } \\
\text { related to sense, movement, } \\
\text { sizes, and behaviors. }\end{array}$ & $\begin{array}{l}\text { - Sun/shade } \\
\text { - Warmth/cool } \\
\text { - Breeze/ventilation }\end{array}$ & $\begin{array}{l}\text { - Good design and detailing } \\
\text { - Views/vistas } \\
\text { - Trees, plants, water }\end{array}$ \\
\hline
\end{tabular}




\subsection{Attributes for Successful ANG}

By acknowledging the discussion in previous sections, the required bunch of attributes has been summarized in Table 3:

Table 3: Successful ANGs have some attributes stated below (Carmona, Heath, Oc \& Tiesdell, 2003)

\begin{tabular}{|c|c|c|c|}
\hline \multirow{2}{*}{$\begin{array}{l}\text { Key Attributes } \\
\text { Comfort and image }\end{array}$} & \multicolumn{2}{|c|}{ Inner ring Intangibles } & \multirow{2}{*}{$\begin{array}{l}\text { Outer ring Measurable } \\
\text { - Crime statistics } \\
\text { - Sanitation rating } \\
\text { - Building conditions } \\
\text { - Environmental data }\end{array}$} \\
\hline & $\begin{array}{l}\text { - Safety } \\
\text { - Charm } \\
\text { - History } \\
\text { - Attractiveness }\end{array}$ & $\begin{array}{l}\text { - Walkability } \\
\text { - Greenness } \\
\text { - Cleanliness }\end{array}$ & \\
\hline Access and linkage & $\begin{array}{l}\text { - Readability } \\
\text { - Reliability } \\
\text { - Continuity }\end{array}$ & $\begin{array}{l}\text { - Proximity } \\
\text { - Connectedness } \\
\text { - Accessibility }\end{array}$ & $\begin{array}{l}\text { - Traffic data } \\
\text { - Pedestrian activity } \\
\text { - Parking usage pattern }\end{array}$ \\
\hline Uses and activity & $\begin{array}{l}\text { - Sustainability } \\
\text { - Uniqueness } \\
\text { - Affordability } \\
\text { - Fun }\end{array}$ & $\begin{array}{l}\text { - Usefulness } \\
\text { - Celebration } \\
\text { - Vitality } \\
\text { - Indigenousness }\end{array}$ & $\begin{array}{l}\text { - Property value } \\
\text { - Rent levels } \\
\text { - Land use pattern } \\
\text { - Retail sales } \\
\text { - Local business ownership }\end{array}$ \\
\hline Sociability & $\begin{array}{l}\text { - Co-operation } \\
\text { - Welcoming }\end{array}$ & $\begin{array}{l}\text { - Gossip } \\
\text { - Diversity } \\
\text { - Friendliness } \\
\text { - Interactivity }\end{array}$ & $\begin{array}{l}\text { - Streetlife } \\
\text { - Social networks } \\
\text { - Evening use } \\
\text { - No. of women, children, and the } \\
\text { elderly. }\end{array}$ \\
\hline
\end{tabular}

\subsection{Standard Spatial Act for Accessible} Neighborhood Greens

Among these traits, inner ring intangibles correlate with outer ring measures. An increment in inner ring intangible provokes more increment in external ring measures. Acknowledging this assumption this research paper intends to focus on inner ring intangibles, i.e., accessibility and proximity under access and linkage attribute (Table 4) on selected open space at DRA in the later part.

As per DAP, the required green space is $0.42 \mathrm{~km}$ sq. while only $0.38 \mathrm{~km}$ sq. exists (including playgrounds though those are not accessible for all and are not considered in this study) concerning a total of $4.34 \mathrm{~km}$ sq. in the neighborhood. Still, if the focus is on only neighborhood parks, it is $0.16 \mathrm{~km}$ sq. which is not sufficient by planning law. Christopher Alexander's pattern 60 states that people use greens most when are close to their residences or workplaces, indicated in Figure 3. 300 to 400 meters distance can be seen as a typical threshold value after which the use frequency starts to decline (Suchana, 2013; Nielsen \& Hansen, 2007). The following table conveys the area/size of green spaces according to various authorities of Dhaka.

Table 4: Space standards for urban community facilities in acres by population size.

\begin{tabular}{|l|l|l|l|l|l|l|l|l|l|l|}
\hline \multirow{2}{*}{$\begin{array}{l}\text { Community } \\
\text { Facilities }\end{array}$} & \multicolumn{9}{|c|}{ Size of Population } & $\begin{array}{l}\text { Faculty per } \\
\mathbf{1 0 0 0} \\
\text { Population }\end{array}$ \\
\cline { 2 - 11 } & $\mathbf{2 5 0 0}$ & $\mathbf{5 0 0 0}$ & $\mathbf{1 0 0 0 0}$ & $\mathbf{1 5 0 0 0}$ & $\mathbf{2 0 0 0 0}$ & $\mathbf{2 5 0 0 0}$ & $\mathbf{5 0 0 0 0}$ & $\mathbf{1 0 0 0 0 0}$ & $\mathbf{1 5 0 0 0 0}$ \\
\hline $\begin{array}{l}\text { RECRIATION-Ground/ } \\
\text { Play-Field }\end{array}$ & 0.5 & 1.0 & 1.0 & 1.2 & 1.6 & 2.0 & 4.0 & 8.0 & 12.0 & 0.08 \\
\hline Park & 0.5 & 1.0 & 1.5 & 1.8 & 2.4 & 3.0 & 6.0 & 12.0 & 18.0 & 0.12 \\
\hline
\end{tabular}




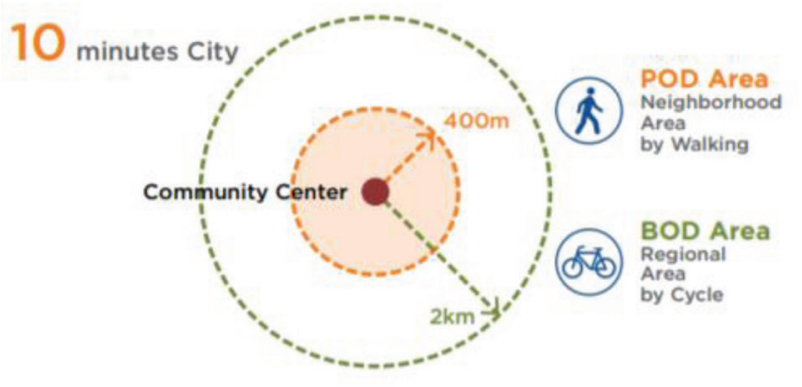

Figure 2: Diagram of Pedestrian Accessible Range by Dhaka Structure Plan 2016 (Source: Dhaka Structure Plan 2016-2035 (2016)).

\section{Selection of Study Area}

Dhanmondi, one of the most affluent residential areas in Dhaka city, was planned and developed by the Public Works Department (PWD) according to Dhaka No. 11413 req.-9 December 1952 (Mahabub-Un-Nabi \& Hashem, 2007). Lying in the city's heart, this place is one of the most heavily built-up areas of the city, with an area of about $1.7 \mathrm{sqm}$, which is the home for 23898 households with a population of about 119,500, mostly from the high-income group (Bangladesh Bureau of Statistics (BBS), Statistics and Informatics
Division (SID), Ministry of Planning, Government of the People's Republic of Bangladesh, 2013). Beginning as the residential area for the city's elite, over the decades evolved into a miniature town, where one can find everything from hospitals to malls, schools, banks, offices, and universities. The uncontrolled and unauthorized growth of various urban amenities such as retail centers, hospitals, clinics, schools, and other commercial activities are causing the rapid decline of the open spaces that also used to serve as the social and cultural spaces. Being a miniature city, this place bears a likewise representation of the capital, Dhaka, and thus making this place a study area may help us to evaluate the present condition of the Dhanmondi residential area as well as the entire Dhaka in terms of accessible neighborhood green.

\section{Study Area Profile}

Dhaka Structure Plan 2016-2035 ("Dhaka Structure Plan 2016-2035," 2016) also states under ObjectiveHN 05, 'To ensure the development of healthy and liveable neighborhood' and in Policy-HN/5.1, to 'Create planned and environmentally sound housing neighborhood in the potential urban areas'.

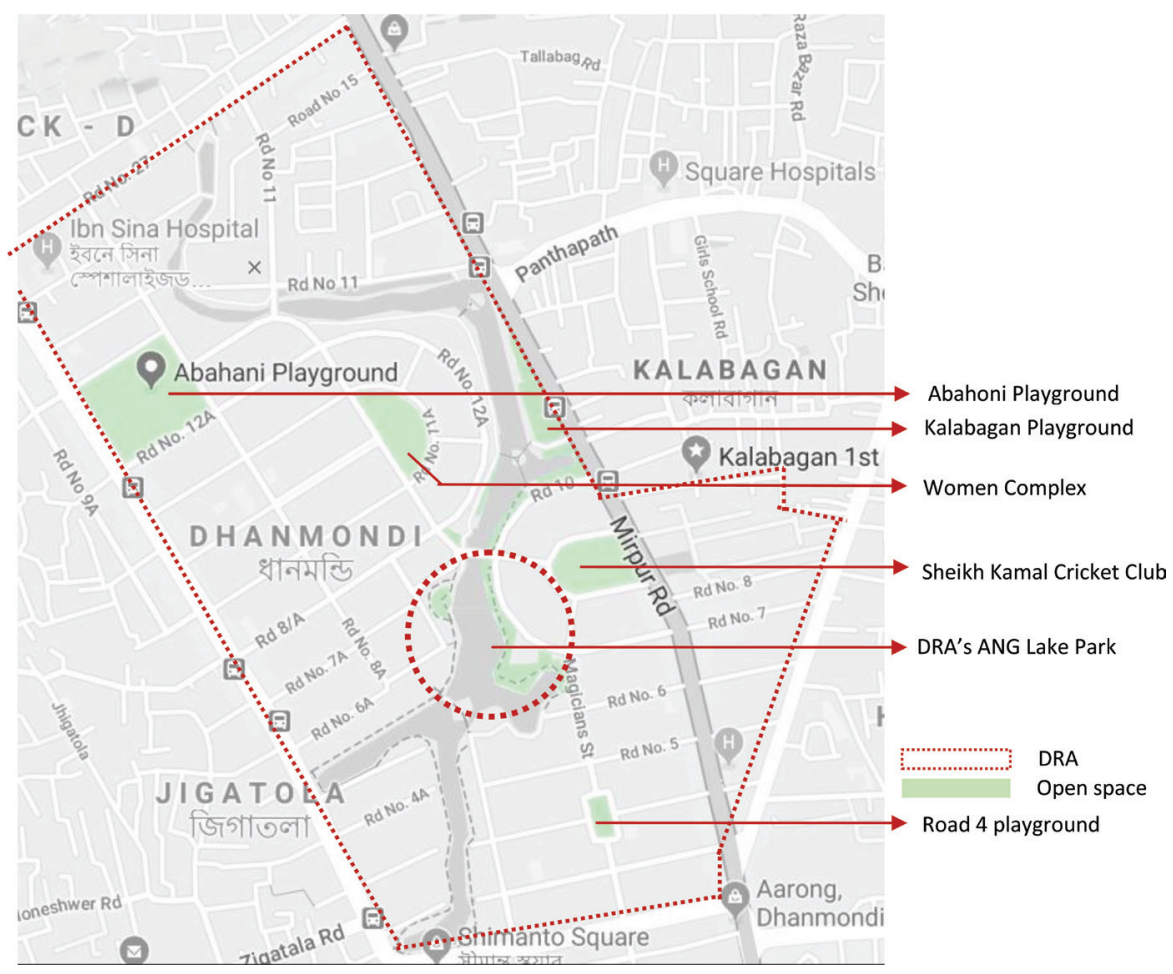

Figure 3: Open spaces in Dhanmondi Residential Area (DRA). 
According to Perry's proposal unit and Dhaka Structure Plan 2016, Dhanmondi Residential Area (DRA) is acceptably facilitated by urban amenities. But in the case of existing ANG of $1 / 4$ mile $(400 \mathrm{~m})$ radius as an acceptable range in percentage with a total of $4.43 \mathrm{~km}$ sq. Residential area raises questions. Among notable six designed open spaces, four, i.e., Abahoni playground, road four local playgrounds, Sheikh Kamal Cricket club and Kalabagan playground are occupied and local timing to neighborhood people and limited for the specific age group. DRA seems like a flourishing neighborhood in terms of sufficiency, yet it is not easily accessible. Existing open spaces along with the study area are marked on the base map of Dhanmondi (Figure 3).

Acknowledging this issue among the existing 6 open parks in DRA only ANG Lake Park qualifies to be studied as it is open for all age groups and is accessible by foot. Figure 4 illustrates the theoretical user radius and primarily used space around the DRA Lake area as ANG.

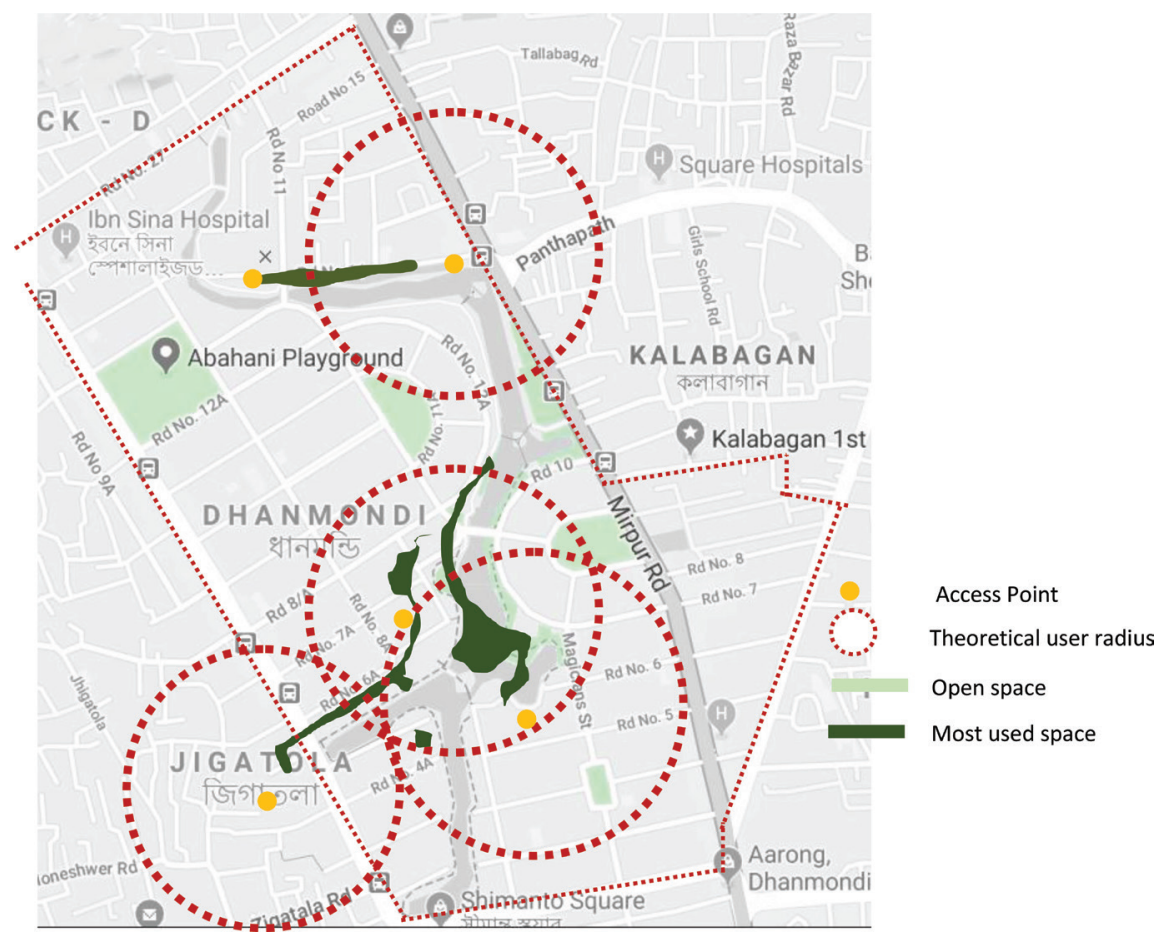

Figure 4: Mostly Used Area of Dhanmondi Lake Park.

\section{Objective and Methodology of Study}

The objective of this research focuses on examining the quality of the physical environment of Neighbourhood public open spaces termed here as accessible neighborhood green (ANG) in the planned Dhanmondi Residential Area (DRA) to examine its adequacy concerning proportion and distance synchronized with the frequency of visits. The initial part of the paper focuses on conceptualizing the problem vis-àvis the existing scenario. Under Qualitative Research Approach, surveys and interviews have been conducted to assess people's perceptions regarding comfort, accessibility, sociability, and user frequency aligned with proximity. Regarding this problem, a physical survey in the neighborhood has been conducted to examine the spatial performance of ANG, user satisfaction, and user frequency from an interactive, accessible distance. Additionally, knowledge from relevant literature reviews has reinforced the collected survey data and interviews to analyze and synthesize properly. For the intentions stated above an extensive survey has been conducted in two-phase:

a) Evaluating the quality of physical \& psycho-physical environment (Observation \& Questionnaire Survey) 
b) Analysing the binding effect of distance - proximity analysis (Field Survey).

The study process is summarized in the Figure 5.

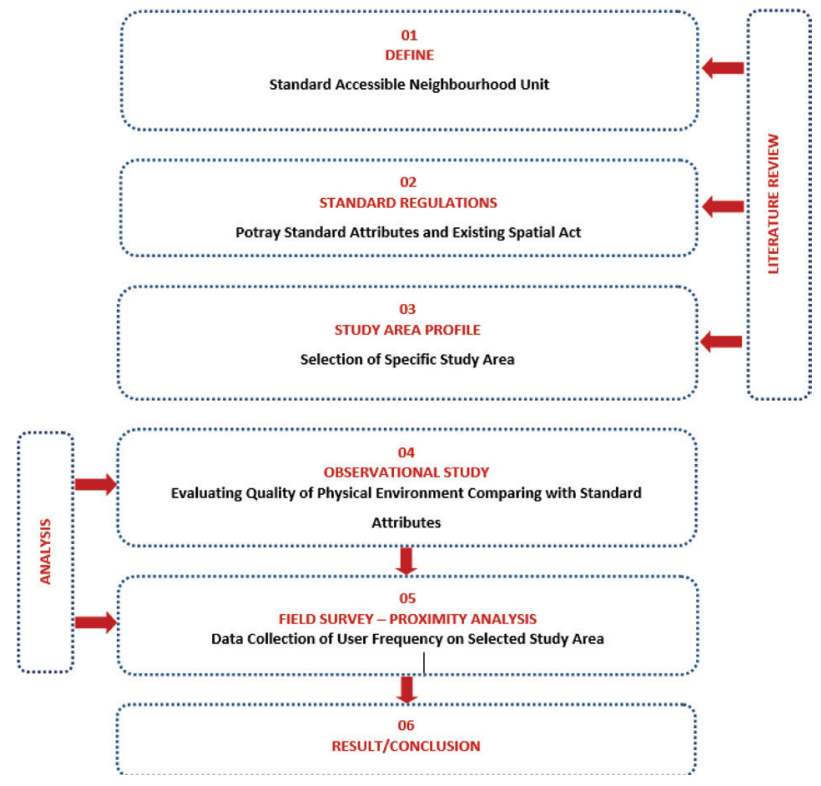

Figure 5: The Qualitative Research Process.

\section{PHASE 01: Observational Study}

Evaluation of the quality of the physical environment in terms of comfort, access linkage, user frequency, and sociability on selected ANGs of DRA has been derived from on the spot interviews of 20 residents concerning relating the attributes stated in Table 4, from each 4 access point shown in Figure 4.

\section{PHASE 02: Field Survey}

To study the influence of distance on such parks' effectiveness, a questionnaire survey has been performed on over 25 individuals who were used to come over there frequently and how far they had to walk to the park. Especially three key questions were asked here.

A. How do you define open or Green spaces?

B. Any suggestion for the Green space planning of a city?

C. What are the significant factors/components of urban blue/green spaces that significantly impact physical activities and mental health well-being?

D. Did a person prefer to walk or use a drive?

E. How many blocks a person has to cross over to reach the preferable ANG?

F. How frequently in a week a person visit this ANG?

From the observation of the first question, open space is often defined as a genuine piece of land accessible to the general public and not intensively developed for residential commercial, or institutional use.

Secondly, Question B's critical purpose is to justify the present green-spaces in DRA, then to detect the areas which require optimization (patch size, connectivity, etc). Practically, this question's intention can help to organize a plan for future green space construction within the city.

Thirdly, we defined the indicator of green space accessibility as a proportion of an urban population living within a certain distance from a green space boundary. We developed a Geographic Information System (GIS)-based method. Population data, maximum distances to green spaces, minimum sizes of green spaces, and different definitions of green spaces were studied or discussed several times. Our GIS mapping and questionnaire observation confirmed that with the increasing length of green space and decreased distance to green space, the indicator value decreased. Comparison supported reviewing the literature and the case studies on Malmö and Utrecht demonstrates that a comparatively more significant proportion of the population has access to large green spaces at both shorter and longer distances. A $300 \mathrm{~m}$ maximum linear distance to the boundary of urban green spaces of a minimum size of 1 hectare is recommended (Bosch et al., 2015). The indicator can stimulate policy actions that recognize the importance of green spaces for sustainable public health.

Through the last question here, rejection has been done who used to drive to this destination. The second question helps to mark the location on the map for distance demarcation. The third question measured frequency, i.e. the number of epochs per week a person comes to the ANG Park. For example, if a person came three days ago, here estimation would be that he naturally comes once per week. This seems a more reasonable investigation than asking the regularity directly.

\section{Analysis in Qualitative Approach}

\subsection{Portraying Quality of Physical and Psycho- Physical Environment}

Concerning these laws, it can be inferred that the selected lake park in DRA is not adequate (in terms of distance threshold because of having less 
prominent or no accessibility with surrounding locality) to support the entire population within DRA as an Accessible Green area. In the following Figure 4, accessible Points have been marked where a theoretically accessible user radius of $1 / 4-1 / 2$ mile has been drawn to portray the most favorable part of Lake Park which becomes insufficient for the whole residential area. However, this study intends
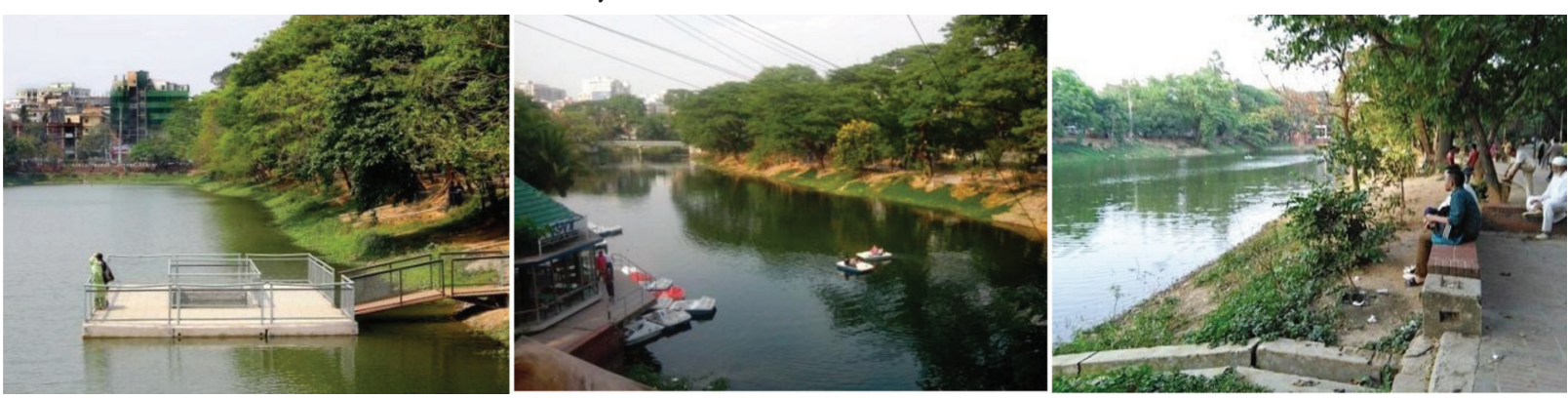

Figure 6: Photographs of Dhanmondi Lake Park.

Table 5: Checklist Analysis (Detail Comparison of Different Standard Attributes on Study Area) for Successful ANG.

\begin{tabular}{|c|c|c|c|}
\hline Key Attributes & \multicolumn{2}{|c|}{ Inner-ring Tangibles } & Outer-ring Measurable \\
\hline Comfort and image & $\begin{array}{l}\text { - Safety } \\
\text { - Charm } \\
\text { - History } \\
\text { - Attractiveness }\end{array}$ & $\begin{array}{l}\text { - Walkability } \\
\text { - Greenness } \\
\text { - Cleanliness }\end{array}$ & $\begin{array}{l}\text { - Crime statistics } \\
\text { - Sanitation rating } \\
\text { - Building conditions }\end{array}$ \\
\hline Access and linkage & $\begin{array}{l}\text { - Readability } \\
\text { - Reliability } \\
\text { - Continuity }\end{array}$ & $\begin{array}{l}\text { - Proximity } \\
\text { - Connectedness } \\
\text { - Accessibility }\end{array}$ & $\begin{array}{l}\text { - Traffic data } \\
\text { - Pedestrian activity } \\
\text { - Parking usage pattern }\end{array}$ \\
\hline Uses and activity & $\begin{array}{l}\text { - Sustainability } \\
\text { - Uniqueness } \\
\text { - Affordability } \\
\text { - Fun }\end{array}$ & $\begin{array}{l}\text { - Usefulness } \\
\text { - Celebration } \\
\text { - Vitality } \\
\text { - Indigenousness }\end{array}$ & $\begin{array}{l}\text { - Property value } \\
\text { - Rent levels } \\
\text { - Retail sales } \\
\text { - Local business ownership }\end{array}$ \\
\hline Sociability & $\begin{array}{l}\text { - Co-operation } \\
\text { - Welcoming }\end{array}$ & $\begin{array}{l}\text { - Diversity } \\
\text { - Friendliness } \\
\text { - Interactivity }\end{array}$ & $\begin{array}{l}\text { - Streetlife } \\
\text { - Social networks } \\
\text { - Evening use }\end{array}$ \\
\hline
\end{tabular}

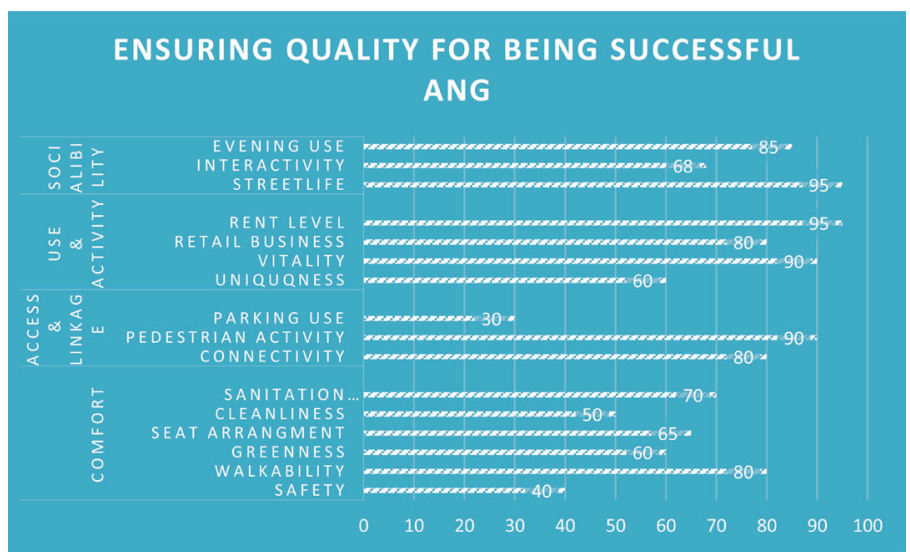

Figure 7: Statistics from Respondents through Questionnaire Survey. 
In Figure 07, statistics from respondents in each access point show that the maximum quality of this lake park's physical environment is satisfactory. But one question remains that, to what percentage of people this open space is beneficial? Proximity or distance decay factor matters here to define practical edge value after which the use occurrence starts to weaken.

\subsection{Proximity Analysis}

In Table 7, the first column portrays the blocks in radius keeping the park in the center, from where people walk regularly. The second column is the circular area measure, which is proportional to the variance of two squares. In the third column, each person comes from different distances multiplied by the trip numbers that they make per week. This clears the total calculation of trip numbers that originates in a particular radius. Fourth column line ups the probability of a person's trip to the park in one week, where trip numbers are divided by the measurement of the rounded area at a certain distance. The fifth column is the logarithm (base 10) of this probability measure p. An evaluation of those facts suggests that an individual's use of the park adjusts drastically if he lives more significantly than three blocks away. It appears then, for mental rest each one and each residence ought to be inside 3-minute walking distance from this park.

Table 6: Data Collection from the Questionnaire Survey.

\begin{tabular}{|c|c|c|c|c|}
\hline $\begin{array}{l}\text { Blocks } \\
\text { (Radius } \\
\text { R) m }\end{array}$ & $\begin{array}{l}\text { Measure of } \\
\text { Area of The } \\
\text { Ring at Radius } \\
\text { R Km }\end{array}$ & $\begin{array}{l}\text { Trips/ } \\
\text { Week }\end{array}$ & $\begin{array}{l}\text { P. (Relative } \\
\text { Probability of } \\
\text { Trips, For Any } \\
\text { One Person) }\end{array}$ & $\begin{array}{l}\text { Log } \\
\text { P }\end{array}$ \\
\hline 1 & 1 & 19.5 & 19.5 & 1.29 \\
\hline 2 & 3 & 26 & 8.7 & 0.94 \\
\hline 3 & 5 & 11 & 2.2 & 0.34 \\
\hline 4 & 7 & 6 & 0.9 & T.95 \\
\hline 5 & 9 & 0 & - & - \\
\hline 6 & 11 & 3 & 0.2 & T.30 \\
\hline 7 & 13 & 0 & - & \\
\hline 8 & 15 & 6 & 0.4 & T.60 \\
\hline 9 & 17 & 2.5 & 0.1 & T.0 \\
\hline
\end{tabular}

In the context of Dhaka, opportunities close to one's house have better elegance than possibilities placed a long way from one's home. Another element associated with measuring accessibility is simulated through social features inclusive of their age, gender, and circle of relative background. These are mostly people-based factors that change over time (i.e. Different in different times of day, week, month, year, etc.).

\section{Discussion and Conclusion}

Dhanmondi Lake Park as ANG acts as a traditional land between the neighborhood and commercial zones and a positive public outdoor space. Though DRA seems to have adequate green space, there is a minimum amount of accessible neighborhood space within; besides being its opening up to the visitors beyond the neighborhood by DRA lake redevelopment, neighborhood privacy has been challenged. Despite deficiency, users prefer this space for being socially interactive, diversified surrounding amenities, and secure green areas with good physical arrangement and maintenance who are close. The internal perimeters are used for passive activities like walking, exercising and social gatherings, increasing during weekends. The neighborhood's privacy is affected due to the influx of outsiders. Old age people are seen to come daily for the morning walk, and in the afternoon, the park's scenario changes with younger people/adults gossiping or sitting. At the same time, others are observed practicing games and exercising in groups in a different part. Local business, retail sales, rent levels, traffic patterns also vary with the change in pedestrian activities in this lake park's periphery. So this ANG lake park has a significant impact and lots of possibilities to serve as a successful ANG (Accessible Neighbourhood Green) within three-minute walking distance.

From the above discussion, it is evident that the provision of ANGs with good spatial patterns becomes the primary attracting feature to enhance the city dwellers' quality of life and the city's liveability. Therefore, it is recommended to build one open public green within two or three blocks apart following the standard distance threshold and standard area.

\section{Acknowledgements}

The paper is a modified version of the author's term paper prepared under Prof. Dr. Qazi Azizul Mowla's guidance for the M.Arch program in DoA, Bangladesh University of Engineering \& Technology - BUET. And also, I am grateful to Ar. Shew wai Ching, Lecturer of Department of Architecture, State 
University of Bangladesh, Dhaka-1205, Bangladesh, for her cordial assistance and support.

\section{References}

Bangladesh Bureau of Statistics (BBS), Statistics and Informatics Division (SID), Ministry of Planning, Government of the People's Republic of Bangladesh (2013). District Statistics 2011 Dhaka. Bangladesh Bureau of Statistics (BBS).

Bosch, M.A. van den, et al. (2015). Development of an urban green space indicator and the public health rationale. Scandinavian Journal of Public Health, 44(2), 159167. https://doi.org/10.1177/1403494815615444

Carmona, M., Heath, T., Oc, T., \& Tiesdell, S. (2003). Public Places Urban Spaces: The Dimensions of Urban Design (2nd Edition). Elsevier Ltd.

'Dhaka Structure Plan 2016-2035' (2016).

EIU Survey: Dhaka ranked second least liveable city (2018, August 15). The Daily Star. Retrieved from

https://www.thedailystar.net/news/city/ dhaka-second-least-liveable-city-in-the-world1620577 \#: - : text $=$ Dhaka $\% 20$ is $\% 20$ the $\% 20$ second $\% 20$ least,Economist $\% 20$ Intelligence $\% 20$ Unit\%20(EIU)

Herzele, A.V., \& Wiedemann, T. (2003). A monitoring tool for the provision of accessible and attractive urban green spaces. Landscape and Urban Planning, 63(2), 109-126.

https://doi.org/10.1016/S0169-2046(02)00192-5
Islam, M.M., Kawsar, M.A., \& Ahmed, R.U. (2002). Open space in Dhaka city: A study on the use of parks in the Dhaka city corporation area. Unpublished BURP thesis, Department of Urban and Regional Planning, Bangladesh University of Engineering and Technology, Dhaka.

Mahabub-Un-Nabi, A.S.M., \& Hashem, M. (2007). Trends of development in Dhanmondi. In: Jahan, S., \& Maniruzzamann K.M. (Eds.), Urbanization in Bangladesh - Patterns, Issues and Approaches to Planning. Bangladesh Institut of Planners, Dhaka, pp. 36-42.

Mirsch, N. (2002). Part IV : Park Definitions \& Development Standards, pp. 1-17.

Mowla, Q.A. (2005). Eco-design concept in the design and management of Dhaka's urban open spaces. In XXII World Congress of Architecture, nia2005istanbul International seminar on Cities- Grand Bazaar of Architectures (sub-theme: Urban Ecology). 3-7 July 2005, Istanbul, Turkey. 233-238.

Nielsen, T.S., \& Hansen, K.B. (2007). Do green areas affect health? Results from a Danish survey on the use of green areas and health indicators. Health \& Place, 13(4), 839-850. https://doi.org/10.1016/j.healthplace.2007.02.001

Suchana, S.B. (2013). Identification and performance evaluation of Christopher Alexander's Pattern 60 in the context of urban Dhaka for liveability. M. Arch Thesis, Bangladesh University of Engineering and Technology (BUET).

\section{旬 CHITKARA}

\section{Creative Space}

Chitkara University, Saraswati Kendra, SCO 160-161, Sector 9-C, Chandigarh, 160009, India

Copyright: [ $(2021$ I.M. Badhan and S.W. Ching] This is an Open Access article published in Creative Space (Creat. Sp.) by Chitkara University Publications. It is published with a Creative Commons Attribution- CC-BY 4.0 International License. This license permits unrestricted use, distribution, and reproduction in any medium, provided the original author and source are credited. 